\title{
RESIDUAL EFFECTS OF NITROGEN FERTILIZER WITH POLYMER-COATED UREA IN A CORN CROP ${ }^{1}$
}

\author{
TAYENE FRANCO MELLO ${ }^{2}$, SALATIÉR BUZETTI², MARCELO CARVALHO MINHOTO TEIXEIRA FILHO², \\ FERNANDO SHINTATE GALINDO ${ }^{2}{ }^{*}$, LAIS MENEGHINI NOGUEIRA ${ }^{2}$
}

\begin{abstract}
The use of nitrogenous fertilizer coated by polymers may reduce losses caused by volatilization, thus exposing this element to plants for a longer period of time. The objective of this work was to evaluate the residual effects of nitrogen in the form of conventional urea and urea coated by polymers in the production components and grain productivity of the first and second corn crops. The experiment was conducted in Selvíria - MS in a clay-type Oxisol during the corn crops of 2011/12 and 2012. The experiment was arranged as a randomized block design with four replications, with a factorial $4 \times 4$ treatment arrangement as follows: 4 doses of $\mathrm{N}\left(0,40,80\right.$ and $\left.120 \mathrm{~kg} \mathrm{ha}^{-1}\right)$ and 4 forms of urea (conventional urea and urea coated by three different polymers). Treatments were applied at the time of corn sowing in the first season (2010/11) and second season (2011). The residual effects of nitrogen fertilization in the corn grown in the first crop season $(2011 / 12)$ and the second crop season (2012) were then assessed. The polymer-coated urea did not differ compared to the conventional urea.
\end{abstract}

Keywords: Zea mays L.. Coated fertilizer. Nitrogen. Improved fertilizer efficiency.

\section{EFEITO RESIDUAL DA ADUBAÇÃO NITROGENADA COM UREIA REVESTIDA POR POLÍMEROS NA CULTURA DO MILHO}

\begin{abstract}
RESUMO - A utilização de fertilizantes nitrogenados revestidos por polímeros pode permitir a redução das perdas por volatilização, disponibilizando assim, esse elemento para as plantas por maior período de tempo. Neste contexto, objetivou-se avaliar o efeito residual de doses de nitrogênio na forma de ureia convencional e ureias revestidas por polímeros, nos componentes de produção e na produtividade da cultura do milho primeira e segunda safra. O experimento foi conduzido em Selvíria - MS, em Latossolo Vermelho distrófico de textura argilosa, em 2011/12 e 2012. O experimento foi disposto em blocos casualizados com quatro repetições, e os tratamentos em um esquema fatorial 4 x 4, sendo: 4 doses de $\mathrm{N}\left(0,40,80\right.$ e $\left.120 \mathrm{~kg} \mathrm{ha}^{-1}\right)$ e 4 formas de ureia (ureia convencional e ureias revestidas por 3 diferentes polímeros). Os tratamentos foram aplicados na semeadura do milho na primeira safra (2010/11) e segunda safra (2011), sendo avaliado o efeito residual da adubação nitrogenada no cultivo sucessor de milho na primeira safra (2011/12) e segunda safra (2012). As formas de ureia revestidas por polímeros não diferiram em relação à ureia convencional.
\end{abstract}

Palavras-chave: Zea mays L.. Fertilizante revestido. Nitrogênio. Fertilizantes de eficiência aprimorada.

\footnotetext{
*Corresponding author

${ }^{1}$ Received for publication in $03 / 05 / 2016$; accepted in 10/18/2016

Paper extracted from the completion of course work of the first author.

${ }^{2}$ Department of Phytosanitary, rural engineering and soils, Universidade Estadual Paulista "Júlio de Mesquita Filho" Ilha Solteira, SP, Brazil; tayfmello@gmail.com, sbuzetti@agr.feis.unesp.br, mcmtf@yahoo.com.br, fs.galindo@bol.com.br, lais-meneghini@hotmail.com.
} 


\section{INTRODUCTION}

Corn is one of the oldest and most broadly disseminated crops in the world. However, despite the available technological advances in corn growing, the average productivity of corn agriculture in Brazil is still very low, approximately $5401 \mathrm{~kg} \mathrm{ha}^{-1}$ for both the first and second harvest. This productivity level demonstrates the need to seek management techniques in order to increase productivity and guarantee profits for the producer (CONAB, 2015).

One of the determinants of production is the ability to obtain nutrients and provide them to the crop. Among these nutrients, nitrogen participates in the composition of amino acids, protein, chlorophyll and many essential enzymes that stimulate the growth and development of the shoot and root system. $\mathrm{N}$ is therefore absorbed in high quantities by the corn and can act as a limiting reagent in corn productivity. Nitrogen management has been carefully studied in order to improve agricultural efficiency. The need for improvements in nitrogen management exists because most of the soil contains organic $\mathrm{N}$ combinations, which are part of the required medium for plant growth (MALAVOLTA, 2006).

Urea is among the main nitrogen fertilizers and is of fundamental importance in both Brazilian and global agriculture. The high concentration of $\mathrm{N}$ in its composition is important for logistics as it reduces the space required for storage and transportation and decreases the cost per unit of nutrients. Therefore, it reflected in the high use of urea in the nitrogen matrix, comprising approximately $50 \%$ of the applied fertilizer. Even with all these advantages, urea has a high propensity for $\mathrm{N}$ loss of up to $80 \%$ of the total fertilizer applied to the soil (CIVARDI et al., 2011).

Volatilization losses occur as a result of the actuation mechanisms of fertilizer contact with the urease enzyme present in the soil. Thus, various urea-based products have been developed in order to increase the efficiency of its use, promoting technological advances in the field of $\mathrm{N}$ input. Among these advances, there is a search for new coated fertilizers as urea granules coated with various materials (resins, waxes, polymers, etc.) may depend on the characteristics of the polymers and increase efficiency through a gradual nutrient release mechanism (CIVARDI et al, 2011; RODRIGUES et al, 2014). The gradual release of nitrogen fertilizer has several benefits. It increases productivity, reduces labor costs, reduces the necessary number of applications, and limits the negative environmental results by reducing nitrate leaching. When combined with the crop demand and development, such as the climate and soil characteristics of the study area (CIVARDI et al., 2011), these factors are of great agricultural significance. Given the above, nitrogen fertilizer with polymer-coated urea can provide a residual effect on subsequent corn crops due to the slower release of $\mathrm{N}$. This effect improves the nutrition and the development of the corn, which is reflected in an improved productivity. Thus, this study aimed to evaluate the residual effects of different nitrogen doses and either conventional urea or urea coated with different polymers in the production of the first and second crop of corn and grain yield in the soil of the low altitude Cerrado region.

\section{MATERIAL AND METHODS}

The experiment was conducted in the UNESP (FEIS / UNESP) station in Selvíria county - MS, with an altitude of $335 \mathrm{~m}$. The area has been cultivated by annual cotton and corn crops for the last 10 years, with the no-till system being used for the past three years.

According to Embrapa (2013), the soil of the area has been classified as a clay-type of red Oxisol. Based on the Köppen classification, the climate is of the AW type, with tropical and humid weather. There is a rainy season in the summer and a dry season in the winter, with an average annual rainfall of $1,370 \mathrm{~mm}$. The rainfall, air temperature and humidity values recorded during the experiment are shown in Figure 1.

The chemical characteristics of the soil were determined before the experiment began in October 2010, according to the methodology proposed by Raij et al. (2001). The soil characteristics in the layer from 0.0 to $0.20 \mathrm{~m}$ are as follows: $\mathrm{P}($ resin $)=22 \mathrm{mg} \mathrm{dm}{ }^{-3} ;$ M.O. $=32 \mathrm{~g} \mathrm{dm}^{-3}$; $\mathrm{pH}\left(\mathrm{CaCl}_{2}\right)=5.4$; and $\mathrm{K}, \mathrm{Ca}, \mathrm{Mg}, \mathrm{H}+\mathrm{Al}=2.2,30.0$, and 16.0 and $31.8 \mathrm{mmol}_{\mathrm{c}} \mathrm{dm}^{-3}$, respectively, with $60 \%$ base saturation.

The experimental design was a randomized complete block design with four replications in a $4 \mathrm{x}$ 4 factorial, as follows: $4 \mathrm{~N}$ doses $(0,40,80$ and $120 \mathrm{~kg} \mathrm{ha}^{-1}$ ) and 4 forms of urea (conventional urea $45 \% \mathrm{~N}$ and ureas coated by 3 different polymers: K - 0043 with $43.18 \% \mathrm{~N}, \mathrm{~K}-0049$ with $45 \%$ of $\mathrm{N}$ and $\mathrm{K}-0055$ to $41.355 \% \mathrm{~N}$ ). These treatments were applied when the corn was sown in the first season (on November 5 of the 2010/11 season) and in the second season (on May 15, 2011). Coated urea types were identified by codes K - 0043, K - 0049 and $\mathrm{K}-0055$ as these are not yet commercial products. 

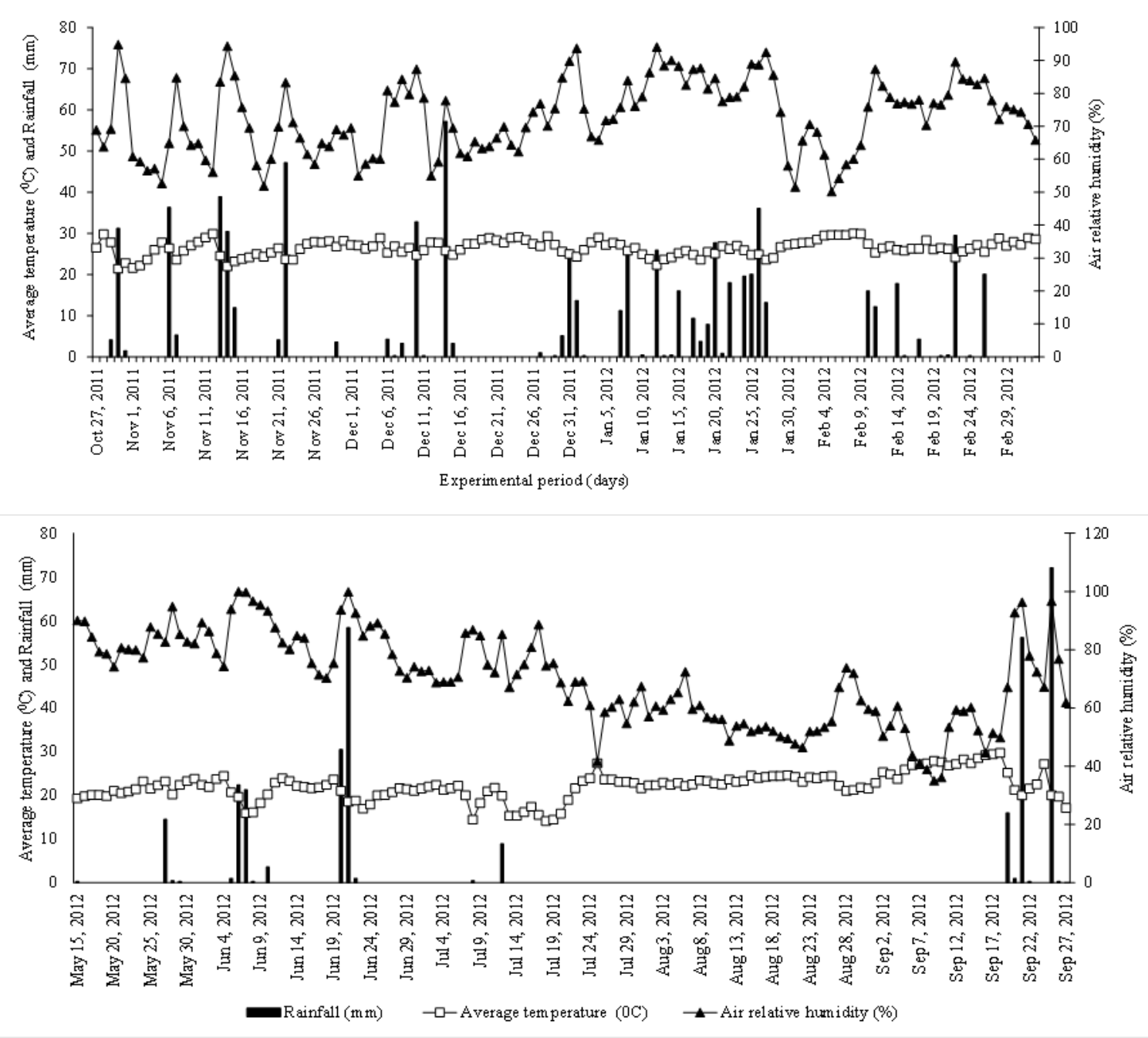

Figure 1. Rainfall, temperature and average relative humidity recorded during the conduct of experiments with corn first crop (A) and second crop (B). The data were obtained from the meteorological station located near the experimental area Selvíria-MS, 2011/12 and 2012.

To evaluate the residual effects of nitrogen fertilization on corn cropped in succession in the first season (2011/12) and the second season (2012), sowing was carried out exactly in the row of the preceding crop. The plots were 5-m long with 4 rows spaced evenly by $0.90 \mathrm{~m}$. The two central rows of each plot were considered to be useful.

Corn sowing was mechanically accomplished with a simple hybrid AGROCERES AG 8088 system on 06/11/2011 and 27/05/2012 in the previously desiccated area (15 days prior) with a mixture of herbicide glyphosate (1800 $\mathrm{g} \mathrm{ha}^{-1}$ ia) and 2,4-D (670 $\mathrm{g} \mathrm{ha}^{-1}$ ai). After seeding, the area was irrigated by sprinkling by means of a central pivot with approximately $14 \mathrm{~mm}$ of water to promote seed germination, with an approximate 3-day irrigation turn. Seedling emergence occurred five days after seeding, both in the first and second harvest.

Fertilization sowing was carried out with $30 \mathrm{~kg} \mathrm{ha}^{-1} \mathrm{~N}$ (urea), $100 \mathrm{~kg} \quad \mathrm{ha}^{-1} \quad \mathrm{P}_{2} \mathrm{O}_{5}$ (superphosphate) and $80 \mathrm{~kg} \mathrm{ha}^{-1} \mathrm{~K}_{2} \mathrm{O}$ (potassium chloride) also for all treatment conditions based on the soil analysis and fertilizer recommendation table for irrigated maize in the state of São Paulo, as described by Cantarella, Raij and Camargo (1997). Importantly, nitrogen fertilization was performed both in the first and second harvest as this fertilization refers to the treatments derived from the residual effect. Weed management in the corn crops was accomplished with the application of Tembotrione herbicide ( $84 \mathrm{~g}$ a.i. ha ${ }^{-1}$ ) and atrazine $\left(1000 \mathrm{~g}\right.$ a.i. $\left.\mathrm{ha}^{-1}\right)$, with the addition of an adjuvant in the spray herbicide and vegetable oil ( $720 \mathrm{~g}$ a.i. $\left.\mathrm{ha}^{-1}\right)$ in the post-emergence time period. The pest control was performed with methomyl (215 g a.i. ha $\left.{ }^{-1}\right)$ and triflumuron $\left(24 \mathrm{~g}\right.$ a.i. ha $\left.{ }^{-1}\right)$.

The corn harvest was performed manually and individually by experimental units in 2011/12 (first crop) to $118 \mathrm{DAE}$ and 2012 (second crop) to 128 DAE, when $90 \%$ of the corn had grains with $20 \%$ moisture. The collected material was dried in full sunlight, and the grains were mechanically separated from the cobs.

The following measurements were carried out in the corn. a) The leaf nitrogen content was assessed according to the methodology proposed by 
Malavolta, Vitti and Oliveira (1997) by collecting 20 sheaves from the middle third area at the insertion of the main spike; in the female floral was collected from each portion according to the methodology of Cantarella, Raij and Camargo (1997). b) The diameter of the second internode stem was measured using a manual paquimeter. c) The insertion height of the first spike was measured, as was d) the plant height at maturity, defined as the distance (m) from the soil level to the tassel apex. e) The number of kernels per row, $f$ ) the number of rows per ear, $g$ ) the number of grains per spike, and h) the weight of 100 grains were measured. The latter was determined using a $0.01 \mathrm{~g}$ precision balance with the grain-water content adjusted to $13 \%$ (wet basis). i) The grain yield was determined by collecting the plants contained in the 2 -axis of each plot. The material was subjected to drying in full sun, and after the mechanical track, the grains were measured, and the data was processed in $\mathrm{kg} \mathrm{ha}^{-1}, 13 \%$ (wet basis).

The variables were subjected to an analysis of variance ( $F$ test), and the average forms of urea were compared by Tukey's test at 5\% probability. The $\mathrm{N}$ doses were used for regression analysis to 1 and $5 \%$ significance levels. Statistical analysis was accomplished using the SISVAR program (FERREIRA, 2011).

\section{RESULTS AND DISCUSSION}

For 2011/12, there were no significant differences between the urea forms and the stem diameter, plant height, ear insertion height, number of kernels per row, row number per ear, number of grains per ear, mass of 100 grains and maize grains (Tables 1 and 2). These findings demonstrated that the improved efficiency of urea was not superior compared to that of conventional urea in terms of any residual effect on subsequent corn cultivation.

The results for the second season, in 2012, were similar results to corn grown in the previous season, in which there were no significant correlation between the forms of urea and the stem diameter, plant height, ear insertion height, number of grains per row, row per ear and grains per ear, weight of 100 grains and corn grains (Tables 1 and 2).

Table 1. Stem diameter, plant height, ear insertion height and leaf $\mathrm{N}$ concentration in the first and second crop corn due to the residual effect of urea forms and nitrogen doses. Selvíria-MS, 2011/12 and 2012.

\begin{tabular}{|c|c|c|c|c|c|c|c|c|}
\hline \multirow[t]{2}{*}{ Treatment } & \multicolumn{2}{|c|}{$\begin{array}{l}\text { Stem diameter } \\
(\mathrm{cm})\end{array}$} & \multicolumn{2}{|c|}{$\begin{array}{l}\text { Plant height } \\
\text { (m) }\end{array}$} & \multicolumn{2}{|c|}{$\begin{array}{l}\text { Ear insertion height } \\
(\mathrm{m})\end{array}$} & \multicolumn{2}{|c|}{$\begin{array}{l}\text { Leaf } \mathrm{N} \text { concentration } \\
\quad\left(\mathrm{g} \mathrm{kg}^{-1} \text { of } \mathrm{DM}\right)\end{array}$} \\
\hline & $2011 / 12$ & 2012 & $2011 / 12$ & 2012 & $2011 / 12$ & 2012 & $2011 / 12$ & 2012 \\
\hline \multicolumn{9}{|l|}{ Urea forms } \\
\hline $0055^{(1)}$ & $2.12 \mathrm{a}$ & $2.08 \mathrm{a}$ & $2.58 \mathrm{a}$ & $2.52 \mathrm{a}$ & $1.13 \mathrm{a}$ & $1.11 \mathrm{a}$ & 33.29 a & $24.22 \mathrm{a}$ \\
\hline $0043^{(2)}$ & $2.10 \mathrm{a}$ & $2.09 \mathrm{a}$ & $2.60 \mathrm{a}$ & $2.53 \mathrm{a}$ & $1.14 \mathrm{a}$ & $1.12 \mathrm{a}$ & $33.57 \mathrm{a}$ & $24.05 \mathrm{a}$ \\
\hline $0046^{(3)}$ & $2.23 \mathrm{a}$ & $2.10 \mathrm{a}$ & $2.63 \mathrm{a}$ & $2.57 \mathrm{a}$ & $1.15 \mathrm{a}$ & $1.13 \mathrm{a}$ & $33.09 \mathrm{a}$ & $24.51 \mathrm{a}$ \\
\hline $0049^{(4)}$ & $2.10 \mathrm{a}$ & $2.12 \mathrm{a}$ & $2.64 \mathrm{a}$ & $2.60 \mathrm{a}$ & $1.15 \mathrm{a}$ & $1.15 \mathrm{a}$ & $33.20 \mathrm{a}$ & $23.39 \mathrm{a}$ \\
\hline LSD (5\%) & 0.16 & 0.17 & 0.09 & 0.15 & 0.05 & 0.05 & 1.59 & 2.62 \\
\hline \multicolumn{9}{|l|}{$\mathrm{N}$ doses $\left(\mathrm{kg} \mathrm{ha}^{-1}\right)$} \\
\hline 0 & 2.15 & 1.94 & 2.59 & 2.39 & 1.13 & 1.08 & 32.90 & 24.14 \\
\hline 40 & 2.17 & 2.19 & 2.60 & 2.63 & 1.15 & 1.15 & 33.40 & 24.27 \\
\hline 80 & 2.09 & 2.08 & 2.59 & 2.63 & 1.13 & 1.15 & 33.74 & 23.52 \\
\hline 120 & 2.14 & 2.17 & 2.67 & 2.57 & 1.16 & 1.15 & 33.11 & 24.24 \\
\hline C.V. $(\%)$ & 8.05 & 8.59 & 3.70 & 6.34 & 5.15 & 5.13 & 3.31 & 7.56 \\
\hline Overall mean & 2.14 & 2.10 & 2.61 & 2.56 & 1.14 & 1.13 & 33.29 & 24.04 \\
\hline
\end{tabular}

Followed measures by the same letter within each parameter studied, do not differ by Tukey test at $5 \%$ probability of error.

(1) Urea coated with $41,355 \%$ de N.

(2) Urea coated with $43,18 \%$ de N.

(3) Conventional Urea $45 \%$ de $\mathrm{N}$.

(4) Urea coated with $45 \%$ de N. 
T. F. MELLO et al.

Table 2. Numbers of grain per row, rows per ear and grains per ear, weight of 100 grains and productivity of first corn kernels and second crop due to the residual effect of urea forms and nitrogen doses. Selvíria-MS, 2011/12 and 2012.

\begin{tabular}{|c|c|c|c|c|c|c|c|c|c|c|}
\hline \multirow[t]{2}{*}{ Treatment } & \multicolumn{2}{|c|}{ Grain per row } & \multicolumn{2}{|c|}{ Rows per ear } & \multicolumn{2}{|c|}{ Grains per ear } & \multicolumn{2}{|c|}{$\begin{array}{l}\text { Weight of } 100 \text { grains } \\
\text { (g) }\end{array}$} & \multicolumn{2}{|c|}{$\begin{array}{l}\text { Grain productivity } \\
\quad\left(\mathrm{kg} \mathrm{ha}^{-1}\right)\end{array}$} \\
\hline & $2011 / 12$ & 2012 & $2011 / 12$ & 2012 & $2011 / 12$ & 2012 & 2011/12 & 2012 & 2011/12 & 2012 \\
\hline \multicolumn{11}{|l|}{ Urea forms } \\
\hline $0055^{(1)}$ & $37.5 \mathrm{a}$ & $29.89 \mathrm{a}$ & $18.3 \mathrm{a}$ & $16.85 \mathrm{a}$ & $686 \mathrm{a}$ & $517 \mathrm{a}$ & $27.04 \mathrm{a}$ & $24.03 \mathrm{a}$ & $8223 \mathrm{a}$ & $6893 \mathrm{a}$ \\
\hline $0043^{(2)}$ & $37.4 \mathrm{a}$ & $30.66 \mathrm{a}$ & $18.5 \mathrm{a}$ & $17.13 \mathrm{a}$ & $695 \mathrm{a}$ & $525 \mathrm{a}$ & $26.59 \mathrm{a}$ & $24.07 \mathrm{a}$ & 8190 a & 6564 a \\
\hline $0046^{(3)}$ & $36.9 \mathrm{a}$ & $30.66 \mathrm{a}$ & $18.5 \mathrm{a}$ & $17.13 \mathrm{a}$ & $682 \mathrm{a}$ & $525 \mathrm{a}$ & $26.35 \mathrm{a}$ & $24.11 \mathrm{a}$ & $8190 \mathrm{a}$ & $7081 \mathrm{a}$ \\
\hline $0049^{(4)}$ & $37.4 \mathrm{a}$ & $31.35 \mathrm{a}$ & $18.2 \mathrm{a}$ & $17.13 \mathrm{a}$ & $658 \mathrm{a}$ & $537 \mathrm{a}$ & $27.24 \mathrm{a}$ & $25.22 \mathrm{a}$ & $8340 \mathrm{a}$ & $6812 \mathrm{a}$ \\
\hline $\operatorname{LSD}(5 \%)$ & 1.5 & 1.98 & 0.8 & 0.64 & 42 & 36 & 1.28 & 2.14 & 1039 & 600 \\
\hline \multicolumn{11}{|c|}{$\mathrm{N}$ doses $\left(\mathrm{kg} \mathrm{ha}^{-1}\right)$} \\
\hline 0 & 36.5 & 32.10 & 18.6 & 16.9 & 679 & 542 & 26.32 & 23.61 & 7020 & 6581 \\
\hline 40 & 37.3 & 30.25 & 18.4 & 17.3 & 689 & 522 & 26.79 & 25.08 & 8370 & 6944 \\
\hline 80 & 37.6 & 29.51 & 18.1 & 17.1 & 681 & 503 & 26.85 & 24.04 & 8948 & 6751 \\
\hline 120 & 37.9 & 30.74 & 18.4 & 16.0 & 699 & 523 & 27.27 & 24.68 & 8546 & 7074 \\
\hline C.V. $(\%)$ & 4.38 & 6.85 & 4.76 & 4.00 & 6.48 & 7.29 & 5.08 & 9.31 & 6.70 & 9.30 \\
\hline Overall mean & 37.33 & 30.65 & 18.40 & 17.06 & 687 & 523 & 26.81 & 24.35 & 8220 & 6838 \\
\hline
\end{tabular}

Followed measures by the same letter within each parameter studied, do not differ by Tukey test at $5 \%$ probability of error.

${ }^{(1)}$ Urea coated with $41.355 \%$ de N.

${ }^{(2)}$ Urea coated with $43.18 \%$ de N.

${ }^{(3)}$ Conventional Urea $45 \%$ de N.

${ }^{(4)}$ Urea coated with $45 \%$ de N.

Valderrama et al. (2011) evaluated the conventional urea and improved efficiency urea (coated urea) applied to the same corn crop cycle and also found that there were no significant differences for these same assessments. Working with the urea sources ammonium sulfate and ammonium sulfonitrate, Kappes et al. (2009) also found that there were no significant differences between the measured weight of 100 grains produced through the use of conventional urea or improved-efficiency urea.

The urea forms did not differ for the leaf $\mathrm{N}$ concentrations in either experiment (Table 1), demonstrating that the urea types with different coatings did not affect the nutritional status $(\mathrm{N})$ of the plants. In the corn crop in the 2011/12 season, the values found for the $\mathrm{N}$ levels were adequate according to the recommended values (27-35 $\mathrm{g}$ of $\mathrm{N} \mathrm{kg}^{-1}$ dry matter) for corn, as described in Cantarella, Raij and Camargo (1997). In the second experiment, referring to the second crop corn (2012), the $\mathrm{N}$ levels that were obtained were lower and were below the recommended level, with an overall average of $24 \mathrm{~g}$ of $\mathrm{N} \mathrm{kg}^{-1}$ dry matter, although deficiency symptoms were not noted. This low $\mathrm{N}$ level was a moderate deficiency (hidden hunger) that was caused by the failure to provide the first and second $\mathrm{N}$ evaluated corn crop.

The grain yield from the first and second crops was not affected by the form of urea used during cultivation, demonstrating that the urea coated by polymers of different compositions and concentrations was not better than when using conventional urea (Table 2). Valderrama et al. (2011) also found that there was no difference between using conventional urea and urea coated with polymers in terms of the productivity of the corn grains in the summer crop in the cerrado region. However, Pereira et al. (2009) found that the urea coating and use of a urease inhibitor were effective in reducing the volatilization of $\mathrm{N}$ (by approximately $50 \%$ ), thus resulting in a higher grain yield in the Jataí - GO, in Cerrado region. Of note, that region has a higher altitude and a lower night temperature than the area assessed in the current study. Silva et al. (2012) found that there were no significant differences in the corn yield from different sources when conventional coated urea was applied but that there was increased productivity due to the increased dose of N. In his experiment, there was no direct influence of ammonia volatilization, as the corn plants responded to increased $\mathrm{N}$ doses and probably responded positively to topdressing with a protected urea from the benefits of coating, thus delaying the enzymatic activity of urease. Consequently, this system provided larger amounts of $\mathrm{N}$ compared to the conventional urea system.

According to Rodrigues et al. (2014), the slow or gradual release of fertilizers depends on having water and soil temperatures equal or greater than $21{ }^{\circ} \mathrm{C}$ for the proper release of the nutrients to the plants. Therefore, it is likely that the coating was 
ineffective in the conditions of the present research study, as this work was conducted in low-lying savanna conditions, dominated by the high temperatures and high levels of microorganism activity.

The effectiveness of a coated fertilizer depends on the solubility of the polymer-coated granule and the rate of hydrolysis, which regulates the nutrient supply process. The release rates and dissolution of water-soluble fertilizers depends on the coating materials that are used (RODRIGUES et al., 2013). Yet, according to these authors, nutrient release will also depend on the temperature and soil moisture. Furthermore, the thickness and the chemical nature of the coating resin, the amount of microcracks in the surface, and the size of the fertilizer granule will also influence the nutrient
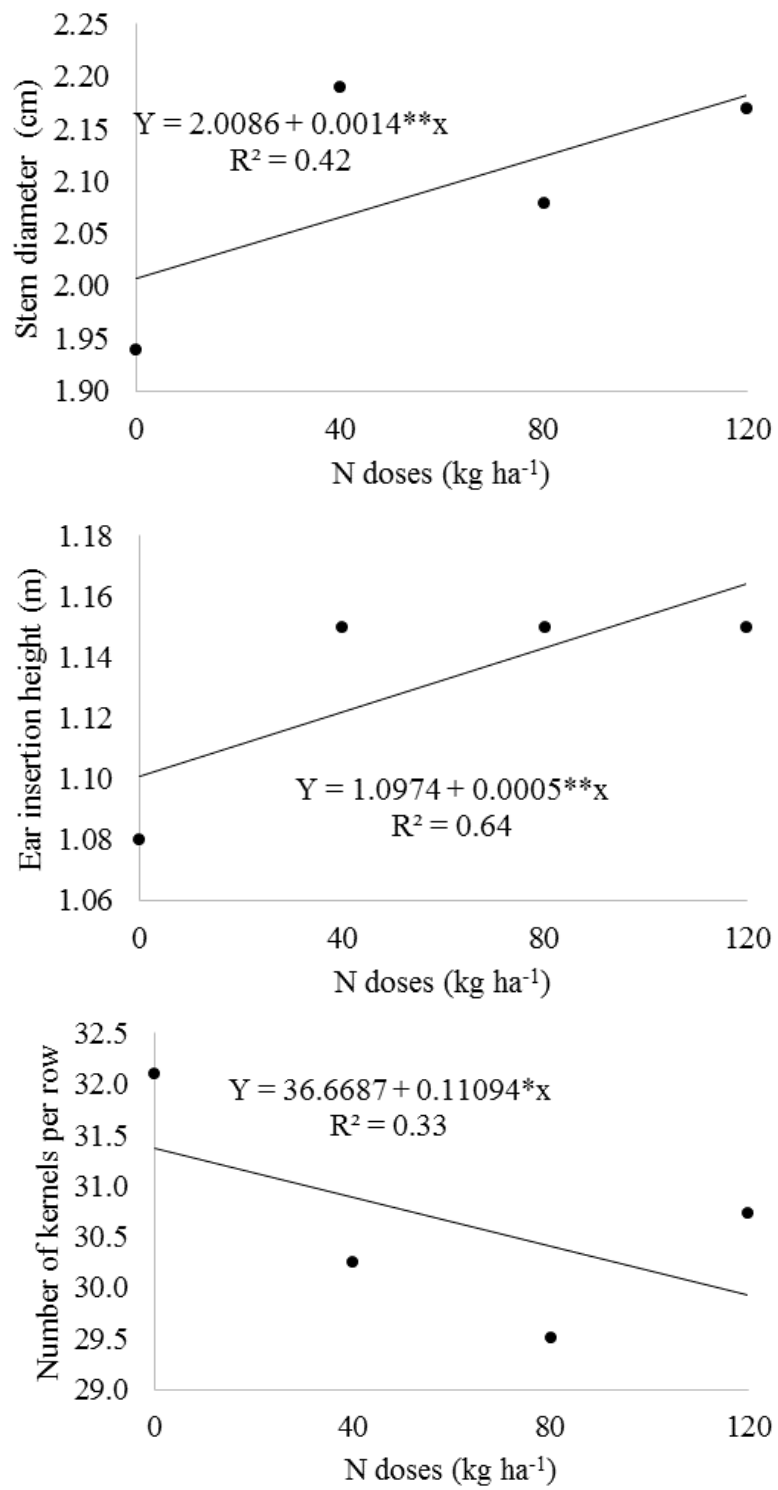

release rate over time (RODRIGUES et al., 2014). Thus, there is still a need for further research to develop new polymers, with the ability to withstand the high temperatures of this common low-altitude cerrado region, for the coating of urea. Of note, the results with polymer-coated urea may vary according to the time of the nitrogen application coverage and the weather conditions during the period of this application and may not have residual effects on succeeding crops beyond urea use alone.

The $\mathrm{N}$ doses had no measurable effects on the stem diameter, plant height and ear insertion height in the 2012 crop (Tables 1 and 2). We adjusted the increasing linear function for stem diameter and ear height and adjusted the quadratic function for plant height, with a positive response to the dose of $70 \mathrm{~kg} \mathrm{ha}^{-1} \mathrm{~N}$ (Figures 2A, 2B and 2C).
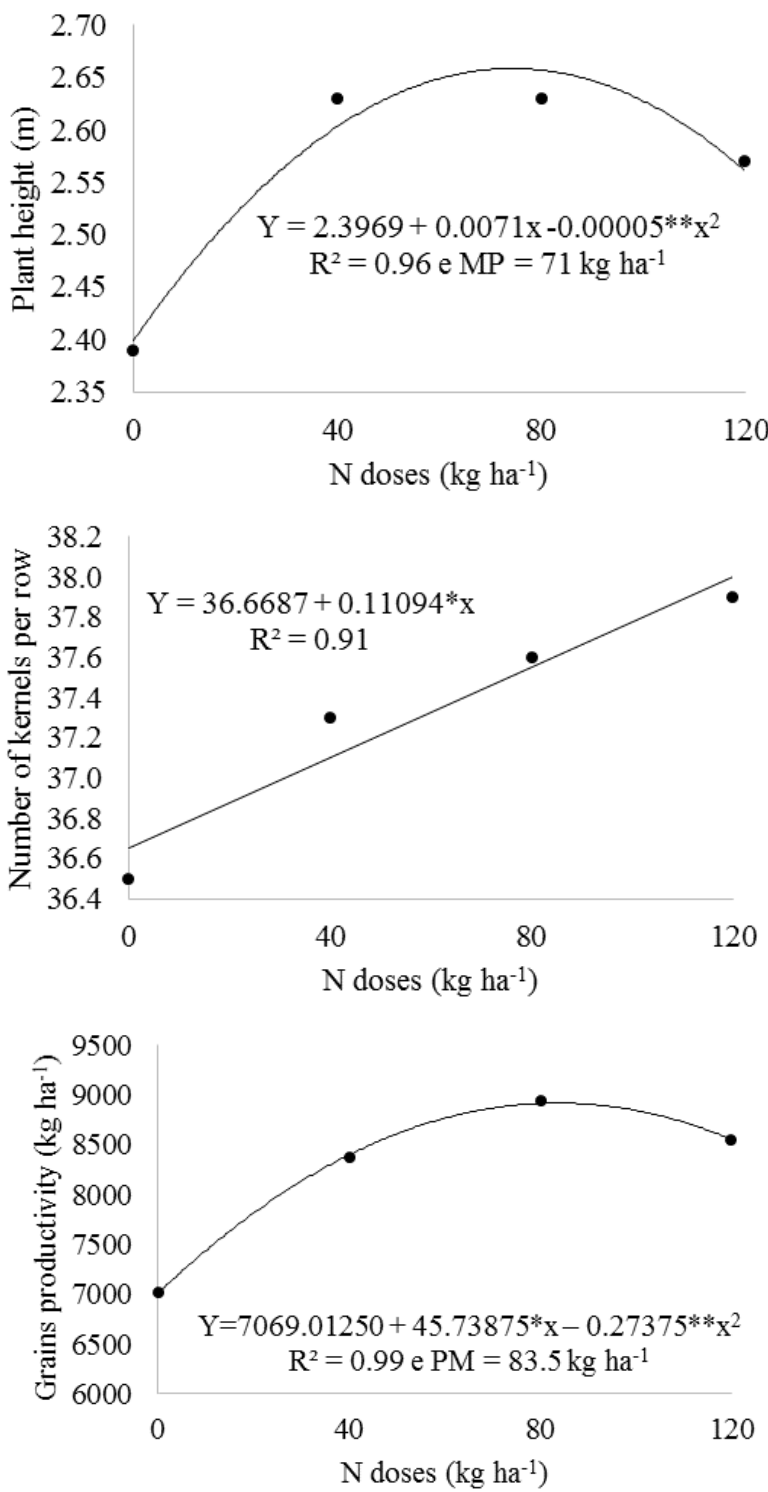

Figure 2. Stem diameter in 2012 (A), plant height in 2012 (B), ear insertion height in 2012 (C), number of kernels per row in 2011/12 (D) and 2012 (E) and productivity of corn grains in 2011/12 (F), in function of the $\mathrm{N}$ doses residual. Selvíria - MS, 2012.

** significant $\mathrm{p}<0.01$

* significant $0.01<\mathrm{p}<0.05$

ns: not significant. 
The plant height is influenced by the $\mathrm{N}$ that is available in the soil since this nutrient is directly involved in the cell division and expansion and the photosynthetic process. This would explain the positive response of $\mathrm{N}$ doses on growth in the height of corn plants and is consistent with the data of Gross, Pinho and Brito (2006), who cited that the nitrogen fertilization, either performed in coverage in an application or split into two treatments, positively influences growth, as measured by plant height and ear height, with meaningful reflection on the productivity of corn grain. However, it is noteworthy that the plant height is not always correlated with productivity as modern hybrids with high yield potential are mostly of short height (CRUZ et al., 2008).

Regarding the insertion height of the main ear feature, the results were consistent with those obtained by Souza and Soratto (2006) and Lana et al. (2009). These researchers assessed the response of corn growth to $\mathrm{N}$ application and found that the main tang insertion height was higher in corn treated with $\mathrm{N}$ compared to the control corn. A well-nourished plant shows further development of the leaf area and roots since this nutrient influences division, cell growth and photosynthesis, which can lead to increased plant height and consequently, an insertion height spike.

Regarding the stem diameter, the results obtained in 2012 agree with those found by Cruz et al. (2008), Lana et al. (2009), and Kappes et al. (2013), who found an increase in stem diameter in response to doses of $\mathrm{N}$ in corn. However, contrary results were reported by Costa et al. (2012) in the stem diameter. According to the authors, $\mathrm{N}$ doses did not affect the plant height or height of insertion of the main spike.

There was no dose adjustment needed based on the $\mathrm{N}$ content in the corn leaves from the two crops (Table 1). However, when studying the sources of $\mathrm{N}$ urea, including ammonium sulfate and ammonium starea sulfonitrate, Soratto et al. (2010) found an effect of the $\mathrm{N}$ levels in the second crop. Similarly, Costa et al. (2012), using urea as the N source, found positive and linear effects of $\mathrm{N}$ levels in the leaf tissue at doses of 120 and $200 \mathrm{~kg} \mathrm{ha}^{-1} \mathrm{~N}$. In turn, Souza et al. (2011) observed an average increase in the leaf $\mathrm{N}$ concentrations of up to $183 \mathrm{~kg} \mathrm{ha}^{-1} \mathrm{~N}$, with the urea sources ammonium sulfate and ammonium sulfonitrate.

Nitrogen doses influenced the number of kernels per row in 2011/12 and 2012 and the grain yield in 2011/12 (Table 2). The increment of $\mathrm{N}$ doses provide increasing linear function for the number of grains per row in the cultivation of the crop and adjusted to the decreasing linear function in the subsequent crops (Figures 2D and 2E). The quadratic function was used for the grain yield, with the maximum dose of $83.5 \mathrm{~kg} \mathrm{ha}^{-1} \mathrm{~N}$ (Figure $2 \mathrm{~F}$ ).

According to Lopes et al. (2007), the ear characteristics are dependent on the genotype. It is estimated that the hybrid is responsible for $50 \%$ of the final grain yield. In this way, when the hybrid expresses all of its genetic potential, environmental factors, including available water, nutrients, and temperature, are all critical. The increase in nitrogen levels provides the best development and grain filling due to higher accumulations of $\mathrm{N}$, with a positive impact on the nutritional status of the plant in 2011/12, enabling gene expression of the material in the number of kernels per row, which was not verified in 2012 .

The $\mathrm{N}$ doses did not affect the weight of 100 grains in either evaluated crop (Table 2). According to Ohland et al. (2005), the grain mass is a characteristic influenced by the genotype, nutrient availability and climate conditions during the grain filling stages. The grain mass has high dependence on the $\mathrm{N}$ uptake by maize, which reaches a peak during the period from the beginning of flowering and early grain formation. $\mathrm{N}$ deficiency in this period can contribute to the formation of grains with a lower density due to the non-translocation of nutrients in suitable amounts. Since the variation in the grain yield was not verified to depend on the dose, the soil has provided sufficient $\mathrm{N}$ for the proper development and filling of the crop grain due to the residual effect. It is noteworthy that the values obtained for the weight of 100 grains are considered low as they were below 30 grams and were probably influenced by the low availability of soil water in the critical period of grain filling, even with center pivot sprinkler irrigation.

Several studies have reported increases in the productivity of corn kernels with the application of $\mathrm{N}$ doses (LANA et al, 2009; GOES et al, 2014; KAPPES et al, 2014), reinforcing the results. Meira et al. (2009) observed that the losses by volatilization of $\mathrm{NH} 3$, between the various fertilizers, including urea, were not reflected in the yield of corn. Thus, larger grain yields were obtained when $\mathrm{N}$ was given at higher doses or when $\mathrm{N}$ was more available in the soil solution in the period in which the plant requires a larger amount of nutrients.

In the 2011/2012 crop, the maximum productivity was approximately $8980 \mathrm{~kg} \mathrm{ha}^{-1}$, which was achieved with a dose of $83.5 \mathrm{~kg} \mathrm{ha}^{-1} \mathrm{~N}$. In relationship to the control (without nitrogen fertilizer) this productivity represented an increase of approximately $28 \%$ in the grain yield. Similarly, Amaral Filho et al. (2005) found a linear fit for the grain yield, achieving a maximum of $8,907 \mathrm{~kg} \mathrm{ha}^{-1}$, a value that is close to that found in this work. However, they used an application of $150 \mathrm{~kg} \mathrm{ha}^{-1} \mathrm{~N}$.

In the subsequent crop, the maximum yield was $7,074 \mathrm{~kg} \mathrm{ha}^{-1}$ with $120 \mathrm{~kg} \mathrm{ha}^{-1} \mathrm{~N}$, representing an increase of $7 \%$ compared to the control without fertilization. Fernandes et al. (2005), evaluating the efficiency of $\mathrm{N}$ doses $\left(0,30,90\right.$ and $\left.180 \mathrm{~kg} \mathrm{ha}^{-1}\right)$ in six cultivars of irrigated corn in the region of

Rev. Caatinga, Mossoró, v. 30, n. 3, p. 586 - 594, jul. - set., 2017 
Selvíria - MS, found that the highest average yield was achieved with an estimated $110 \mathrm{~kg} \mathrm{ha}^{-1} \mathrm{~N}$ to yield $6,000 \mathrm{~kg} \mathrm{ha}^{-1}$ of grain. In turn, Soratto et al. (2010) also found a positive response to nitrogen fertilization in the second crop corn, which is the largest grain yield obtained with a dose of $120 \mathrm{~kg} \mathrm{ha}^{-1} \mathrm{~N}$.

The increase in the nitrogen levels provided a residual effect even after two corn crops. However, this positive effect of residual nitrogen fertilization was not reflected in the grain productivity in the second assessed crop. This effect probably occurred because the increase of $\mathrm{N}$ doses had a positive residual effect only on initial plant growth (Figures $2 \mathrm{~A}$ and $2 \mathrm{C}$ ) and was not enough to positively affect the production of the components, which somehow explains the reduction in the number of kernels per row in the second corn crop (Table 2).

The residual effect of nitrogen fertilization after two seasons of cultivation justifies the need for further research on the study of nitrogen sources alternative to urea, seeking not only better efficiency and use of fertilizers but also prolonged residual effects.

\section{CONCLUSIONS}

Polymer-coated urea forms showed the same residual effects as conventional urea, regardless of the $\mathrm{N}$ dose.

Nitrogen fertilization in the previous crop residual effects provided linear increase in the number of kernels per row and productivity of corn grain harvest up to a dose of $83.5 \mathrm{~kg} \mathrm{ha}^{-1} \mathrm{~N}$, in 2011/12.

In the second harvest, the residual $\mathrm{N}$ level increment only positively influenced the corn of early growth (diameter of stem and plant height and ear insertion), regardless of the form of urea.

\section{REFERENCES}

AMARAL FILHO, J. P. R. et al. Espaçamento, densidade populacional e adubação nitrogenada na cultura do milho. Revista Brasileira de Ciência do Solo, Viçosa, v. 29, n. 3, p. 467-473, 2005.

CANTARELLA, H.; RAIJ, B. van.; CAMARGO, C. E. O. Cereais. In: RAIJ, B. van. et al. (Eds.). Recomendações de calagem e adubação para o Estado de São Paulo. Campinas: Instituto Agronômico de Campinas, 1997. v. 1, cap. 13, p. 45-71.

CIVARDI, E. A. et al. Ureia de liberação lenta aplicada superficialmente e ureia comum incorporada ao solo no rendimento do milho.
Pesquisa Agropecuária Tropical, Goiânia, v. 41, n. 1, p. 52-59, 2011.

$\begin{array}{lrr}\text { COMPANHIA } & \text { NACIONAL } & \text { DE } \\ \text { ABASTECIMENTO - CONAB. Avaliação da safra } \\ \text { agrícola } & \mathbf{2 0 1 5} / \mathbf{2 0 1 6} \text { primeiro }\end{array}$
levantamento - outubro/2015. Brasília: CONAB, 2015. Disponível em: < http://www.conab.gov.br/ OlalaCMS/uploads/

arquivos/15_10_09_17_45_57_boletim_graos_outub ro_2015_novo.pdf $>$ Acesso em: 12 out. 2015.

COSTA, N. R. et al. Adubação nitrogenada no consórcio de milho com duas espécies de braquiária em sistema plantio direto. Pesquisa Agropecuária Brasileira, Brasília, v. 47, n. 8, p. 1038-1047, 2012.

CRUZ, S. C. S. et al. Adubação nitrogenada para o milho cultivado em sistema plantio direto, no Estado de Alagoas. Revista Brasileira de Engenharia Agrícola e Ambiental, Campina Grande, v. 12, n. 1, p. 62-68, 2008.

EMPRESA BRASILEIRA DE PESQUISA AGROPECUÁRIA - EMBRAPA. Sistema brasileiro de classificação de solos. 3. ed. Brasília, DF: Embrapa, 2013. 353 p.

FERNANDES, F. C. S. et al. Doses, eficiência e uso de nitrogênio por seis cultivares de milho. Revista Brasileira de Milho e Sorgo, Sete Lagoas, v. 4, n. 2, p. 195-204, 2005.

FERREIRA, D. F. Sisvar: a computer statistical analysis system. Ciência e Agrotecnologia, Lavras, v. 35, n. 6, p. 1039-1042, 2011.

GOES, R. J. et al. Fontes e doses de nitrogênio em cobertura para a cultura do milho em espaçamento reduzido. Revista Agrarian, Dourados, v. 7, n. 24, p. 257-263, 2014.

GROSS, M. R.; PINHO, R. G. V.; BRITO, A. H. Adubação nitrogenada, densidade de semeadura e espaçamento entre fileiras na cultura do milho em sistema plantio direto. Ciência e Agrotecnologia, Lavras, v. 30, n. 3, p. 387-393, 2006.

KAPPES, C.; ARF, O.; ANDRADE, J. A. C. Produtividade do milho em condições de diferentes manejos do solo e de doses de nitrogênio. Revista Brasileira de Ciência do Solo, Viçosa, v. 37, n. 5, p. 1310-1321, 2013.

KAPPES, C. et al. Influência do nitrogênio no desempenho produtivo do milho cultivado na segunda safra em sucessão a soja. Pesquisa Agropecuária Tropical, Goiânia, v. 39, n. 3, p. 251-259, 2009 
KAPPES, C. et al. Manejo do nitrogênio em cobertura na cultura do milho em sistema plantio direto. Revista Brasileira de Milho Sorgo, Sete Lagoas, v. 13, n. 2, p. 201-217, 2014.

LANA, M. C. et al. Arranjo espacial e adubação nitrogenada em cobertura na cultura do milho. Acta Scientiarum. Agronomy, Maringá, v. 31, n. 3, p. 433-438, 2009.

LOPES, S. J. et al. Relações de causa e efeito em espigas de milho relacionadas ao tipo de híbrido. Ciência Rural, Santa Maria, v. 37, n. 6, p. 1536-1542, 2007.

MALAVOLTA, E. Manual de nutrição mineral de plantas. 1. ed. Piracicaba, SP: Editora Ceres, 2006. $631 \mathrm{p}$.

MALAVOLTA, E.; VITTI, G. C.; OLIVEIRA, S. A. Avaliação do estado nutricional das plantas: princípios e aplicações. 2. ed. Piracicaba, SP: POTAFOS, 1997. 319 p.

MEIRA, F. A. et al. Fontes e épocas de aplicação do nitrogênio na cultura do milho irrigado. Semina: Ciências Agrárias, Londrina, v. 30, n. 2, p. 275-284, 2009.

OHLAND, R. A. A. et al. Culturas de cobertura do solo e adubação nitrogenada no milho em plantio direto. Ciência e Agrotecnologia, Lavras, v. 29, n. 3, p. 538-544, 2005.

RAIJ, B. van. et al. Análise química para avaliação da fertilidade de solos tropicais. 1. ed. Campinas, SP: IAC, 2001. 285 p.

PEREIRA, H. S. et al. Ammonia volatilization of urea in the out-of-season corn. Revista Brasileira de Ciência do Solo, Viçosa, v. 33, n. 6, p. 1685-1694, 2009.

RODRIGUES, M. A. C. et al. Adubação com KCl revestido na cultura do milho no Cerrado. Revista Brasileira de Engenharia Agrícola e Ambiental, Campina Grande, v.18, n. 2, p. 127-133, 2014.

RODRIGUES, M. A. C. et al. Cloreto de potássio revestido em efeito residual no feijoeiro de inverno irrigado na região de cerrado. Semina: Ciências Agrárias, Londrina, v. 34, n. 3, p. 1011-1022, 2013.

SILVA, A. A. et al. Aplicação de deferentes fontes de uréia de liberação gradual na cultura do milho. Bioscience Journal, Uberlândia, v. 28, Sup., p. 104-111, 2012.

SORATTO, R. P. et al. Fontes alternativas e doses de nitrogênio no milho safrinha em sucessão à soja.
Revista Ciência Agronômica, Fortaleza, v. 41, n. 4, p. 511-518, 2010.

SOUZA, E. F. C.; SORATTO, R. P. Efeito de fontes e doses de nitrogênio em cobertura, no milho safrinha, em plantio direto. Revista Brasileira de Milho e Sorgo, Sete Lagoas, v. 5, n. 3, p. 395-405, 2006.

SOUZA, J. A. et al. Adubação nitrogenada na cultura do milho safrinha irrigado em plantio direto. Bragantia, Campinas, v. 70, n. 2, p. 447-454, 2011.

VALDERRAMA, M. et al. Fontes e doses de NPK em milho irrigado sob plantio direto. Pesquisa Agropecuária Tropical, Goiânia, v. 41, n. 2, p. 254-263, 2011. 